\title{
Evaluation of the complexity and performance of marine planktonic trophic models
}

\author{
SUZANA G. LELES ${ }^{1}$, JEAN L. VALENTIN ${ }^{2}$ and GISELA M. FIGUEIREDO ${ }^{2}$ \\ ${ }^{1}$ Programa de Pós-Graduação em Ecologia, Departamento de Biologia Marinha, Instituto de Biologia, Universidade \\ Federal do Rio de Janeiro, Av. Prof. Rodolpho Rocco, 211, 21941-902 Rio de Janeiro, RJ, Brasil \\ ${ }^{2}$ Departamento de Biologia Marinha, Instituto de Biologia, Universidade Federal do Rio de \\ Janeiro, Av. Prof. Rodolpho Rocco, 211, 21941-902 Rio de Janeiro, RJ, Brasil \\ Manuscript received on August 11, 2015; accepted for publication on May 4, 2016
}

\begin{abstract}
Planktonic models represent a powerful tool for creating hypotheses and making predictions about the functioning of marine ecosystems. Their complexity varies according to the number of state variables and the choice of functional forms. We evaluated plankton models during the last 15 years $(n=145)$ with the aims of understanding why they differ in complexity, evaluating model robustness, and describing studies of plankton modelling around the globe. We classified models into four groups: Nutrient-PhytoplanktonZooplankton (NPZ), Nutrient-Phytoplankton-Zooplankton-Detritus (NPZD), Size-Structured (SS) and Plankton-Functional-Type (PFT). Our results revealed that the number of state variables varied according to the question being addressed: NPZ models were more frequently applied in physical-biological studies, while PFT models were more applied for investigating biogeochemical cycles. Most models were based on simple functional forms which neglect important feedback related to control of plankton dynamics. Modelling studies sometimes failed to describe sensitivity analysis, calibration and validation. The importance of testing different functional forms was commonly overlooked, and the lack of empirical data affected the verification of model robustness. Lastly, we highlight the need to develop modelling studies in the Southern Hemisphere, including Brazil, in order to provide predictions that assist the management of marine ecosystems.
\end{abstract}

Key words: ecological modelling, marine plankton, model complexity, trophodynamics.

\section{INTRODUCTION}

Mathematical models enable researchers to synthesize knowledge, test hypotheses, and make predictions using differential equations that simulate properties over time (Franks 2002). In oceanography and marine ecology, numerical modelling allows for investigation of the effects of physical, chemical, and biological processes, separately or in combination, thus reducing the complexity of marine systems. Models can be a powerful tool for the management of marine ecosystems, which relies on understanding how the flow of

Correspondence to: Suzana Gonçalves Leles

E-mail: suzanaleles@gmail.com 
nutrients, especially carbon, and the energy transfer along marine food webs may be altered by pollution, eutrophication of coastal waters, ocean acidification, and climate change (Blackford et al. 2010).

Over the past 25 years, marine plankton models have been used as a platform for investigating from plankton physiology to oceanography (e.g., Fasham et al. 1990, Painting et al. 1993, Dadou et al. 1996, Allen et al. 2004, Baird and Suthers 2007, Arhonditsis et al. 2008, Anderson et al. 2010, Banas 2011, Doron et al. 2013, Yool et al. 2013, Mitra et al. 2014a). Eco-physiological models which account for plankton stoichiometry have been described in the literature and can be used for several purposes, such as explore the effect of gut satiation and prey quality on zooplankton growth (Mitra and Flynn 2006, Merico et al. 2009). Regarding oceanography, models are used to address the effects of upwelling and the action of river plumes on plankton dynamics and key ecological/biogeochemical questions related to the efficiency of carbon transfer along planktonic food webs and the impact of ocean acidification on plankton (e.g., Edwards et al. 2000, Banas et al. 2009, Yool et al. 2013, Mitra et al. 2014a).

Plankton models differ in structure and complexity according to the number of state variables, as well as the functional forms used to configure the equations. They may be simple, comprising a small number of state variables, as with the class of models called NPZ (Nutrient-Phytoplankton-Zooplankton), or more complex, featuring up to 15 state variables, as with PFT (Plankton-Functional-Type) models (Gregg et al. 2003, Moore et al. 2004, Le Quéré et al. 2005). The choice of functional forms is crucial to model performance and can be characterized from simple Michaelis-Menten or Holling-type functions to complex mechanistic (or semi-mechanistic) approaches, as seen in eco-physiological models (Flynn 2001, Bonachela et al. 2011). The emergence of more complex models was made possible by computational advances combined with the increased availability in the literature of information required for model parameterization. Given the large variation in model complexity, we asked whether NPZ models are overly simplistic, and whether more complex models (e.g., PFT) may provide more realistic predictions.

The aim of this review was to evaluate marine plankton model studies from the last 15 years, in order to assess model complexity. We have chosen the 15 years cutoff according to previous reviews regarding plankton and biogeochemical modelling (Franks 2002, Arhonditsis and Brett 2004). We give particular attention to the robustness of models that consider a high number of state variables but retain simple functional forms, ignoring important aspects of plankton physiology and ecology. In evaluating existing studies, we demonstrate that many models fail to accomplish all of the steps required in modelling, discussing the reasons for and consequences of such shortcomings. Finally, we examine the global distribution of plankton modelling studies and identify some geographic areas (e.g., Brazil) where such research is lacking. In synthesizing information regarding planktonic modelling and assessing existing studies, this review may enlighten those who intend to model planktonic systems, providing guidance regarding the choice of functional forms and the costs and benefits of making simple versus complex models. Prior to assessing the use of different models within the literature, we define the different types of plankton models and introduce their key components, the state variables and the approaches used to describe functional forms.

\section{DESCRIPTION OF PLANKTON MODELS}

Planktonic trophic models aim to predict how particular state variables vary over the time. These variables describe quantities as nutrients, number of individuals, and/or biomass (in terms of carbon or other chemical elements). As with the choice of state variables, the performance of any model is influenced by the choice of functional forms. Functional forms are the mathematical functions used to represent the processes that 
affect a certain state variable over time, such as nutrient uptake by phytoplankton. The state variables within a given model are linked by 'transfer functions' that are characterized by particular functional forms. Below, we introduce the different types of plankton models, as characterized by the type and number of state variables and discuss three 'transfer functions' common to all planktonic trophic models.

NPZ MODELS “NUTRIENT-PHYTOPLANKTON-ZOOPLANKTON”

NPZ models, which emerged from the pioneering studies of Riley (1946) and Steele (1958), consist of three differential equations and, therefore, three state variables: phytoplankton, zooplankton and nutrients (Fig. 1a). Notably, NPZ models do not account for the size of organisms. A general model can be described by Equations 1, 2, and 3 for phytoplankton $(\mathrm{P})$, zooplankton $(\mathrm{Z})$, and nutrients $(\mathrm{N})$, respectively. The state variables are linked via the uptake of nutrients by phytoplankton $(\mathrm{A}(\mathrm{N}))$, phytoplankton grazing by zooplankton $(\mathrm{G}(\mathrm{P})$ ), and the loss terms of phyto- $(\mathrm{L}(\mathrm{P}))$ and zooplankton $(\mathrm{L}(\mathrm{Z})$ ) due to death (including excretion and predation by higher trophic levels in the case of zooplankton). The non-assimilated food consumed by zooplankton $((1-\mathrm{e}) \mathrm{G}(\mathrm{P}))$ and the dead material is ultimately recycled and return to the nitrogen pool.

$$
\begin{gathered}
\frac{d P}{d t}=A(N) P-G(P) Z-L(P) P \\
\frac{d Z}{d t}=e G(P) Z-L(Z) Z \\
\frac{d N}{d t}=-A(N) P+(1-e) G(P) Z+L(P) P+L(Z) Z
\end{gathered}
$$

\section{NPZD MODELS “NUTRIENT-PHYTOPLANKTON-ZOOPLANKTON-DETRITUS”}

NPZD models are composed at least by 4 state variables. The simplest configuration results from the addition of detritus to the NPZ model, allowing for the description of the organic matter pool (Dadou et al. 1996, Stickney et al. 2000, Fennel 2010). In this case, rather than returning directly to the N pool, the dead phyto- and zooplankton and the not-assimilated fraction of grazing by zooplankton are accumulated in the detritus (D) compartment. The detritus can be consumed by zooplankton $(\mathrm{G}(\mathrm{D})$ ), and is ultimately recycled again into the N pool (R(D)). The NPZD model is described by Equations 4, 5, 6, and 7 for phytoplankton, zooplankton, nutrients, and detritus, respectively. Differences compared to the corresponding equations used for the NPZ model are highlighted in bold.

$$
\begin{gathered}
\frac{\mathrm{dP}}{\mathrm{dt}}=\mathrm{A}(\mathrm{N}) \mathrm{P}-\mathrm{G}(\mathrm{P}) \mathrm{Z}-\mathrm{L}(\mathrm{P}) \mathrm{P} \\
\frac{\mathrm{dZ}}{\mathrm{dt}}=\mathrm{e} \mathrm{Z}(\mathrm{G}(\mathrm{P})+\mathbf{G}(\mathbf{D}))-\mathrm{L}(\mathrm{Z}) \mathrm{Z} \\
\frac{\mathrm{dN}}{\mathrm{dt}}=-\mathrm{A}(\mathrm{N}) \mathrm{P}+\mathbf{R}(\mathbf{D}) \mathbf{D}
\end{gathered}
$$




$$
\frac{\mathrm{dD}}{\mathrm{dt}}=\mathrm{L}(\mathrm{P}) \mathrm{P}+\mathrm{L}(\mathrm{Z}) \mathrm{Z}+(1-\mathrm{e}) \mathrm{Z}(\mathrm{G}(\mathrm{P})+\mathrm{G}(\mathrm{D}))-\mathrm{G}(\mathrm{D}) \mathrm{Z}-\mathrm{R}(\mathrm{D}) \mathrm{D}
$$

More complex NPZD models include not only detritus but also bacteria and different forms of nitrogen (nitrate, ammonium and dissolved organic nitrogen) as state variables (Fasham et al. 1990, Druon and Le Fèvre 1999, Jackson 2001, Cropp and Norbury 2007) (Fig. 1b). The inclusion of bacteria modifies the above NPZD model equations (except the phytoplankton equation, Eq. 8), as illustrated in Equations 9-12 (changes in bold). In this new configuration, the bacteria compartment (B) grows through the uptake of nutrients $(\mathrm{A}(\mathrm{N}))$, also contributing to the recycling of the nutrient pool $(\mathrm{R}(\mathrm{B}))$ and ultimately being consumed by zooplankton $(\mathrm{G}(\mathrm{B}))$.

$$
\begin{gathered}
\frac{d P}{d t}=A(N) P-G(P) Z-L(P) P \\
\frac{d Z}{d t}=e Z(G(P)+G(D)+\mathbf{G}(\mathbf{B}))-L(Z) Z \\
\frac{d N}{d t}=-A(N) P-\mathbf{A}(\mathbf{N}) \mathbf{B}+R(D) D \\
\frac{d D}{d t}=L(P) P+L(Z) Z+(1-e) Z(G(P)+G(D)+G(B))-G(D) Z-R(D) D \\
\frac{d B}{d t}=A(N) B-G(B) Z-R(B) B
\end{gathered}
$$

\section{SS MODELS “SIZE-STRUCTURED”}

As the name implies, Size-Structured (SS) models consider different size classes of plankton (Fig. 1c). This category includes two types of models, the first of which subdivides phyto- and zooplankton compartments into two or more compartments according to cell/individual size, thus increasing the number of state variables (Painting et al. 1993, Gin et al. 1998, Ji et al. 2006, Hinckley et al. 2009). The second type uses allometric relationships (physiological responses according to changes in cell/individual size) to define the parameters, thereby preserving the number of state variables (typically, there are three: nutrient, phytoplankton, and zooplankton). This strategy enables simulation of $n$ size classes of phyto- and zooplankton compartments without changing the number of equations and reducing the number of parameters (Baird and Suthers 2007, Banas 2011, Ward et al. 2012). For example, in the three-compartment model by Banas (2011), the parameter that defines maximum zooplankton ingestion $\left(\mathrm{I}_{0}^{\mathrm{j}}\right.$, where $\mathrm{j}$ represents predator size) is defined based on the prey size ( $\mathrm{x})$ that is accessible for the predator of size $\mathrm{j}\left(\mathrm{x}_{\mathrm{j}}\right)$, as proposed by Hansen et al. (1997):

$$
I_{0}^{j}=\left(26 \text { day }^{-1}\right)\left(\frac{x_{j}}{1 \mu m}\right)^{-0.4}
$$


PFT MODELS “PLANKTON-FUNCTIONAL-TYPE”

According to the number of state variables, PFT models are the most complex models found in the literature, with up to 15 state variables (Allen et al. 2004, Blackford et al. 2004, Le Quéré et al. 2005, Aydin et al. 2005, Megrey et al. 2007, Yool et al. 2013). With the breadth of information related to the biology of planktonic groups that is available in the literature, models that specify different plankton functional groups can be developed to investigate topics such as ocean biogeochemistry (Le Quéré et al. 2005). In this type of model, functional groups have no phylogenetic meaning; rather, they group species on the basis of biogeochemical and/or ecological functions (Le Quéré et al. 2005, Xu and Hood 2006). Such functional groups include picoheterotrophs, phytoplankton calcifiers (e.g., coccolithophorids), nitrogen-fixers organisms (e.g., Trichodesmium), producers of dimethylsulphoniopropionate (DMSP) (e.g., Phaeocystis), phytoplankton silicifiers (diatoms), protozooplankton, and mesozooplankton (Fig. 1d).

a) NPZ type

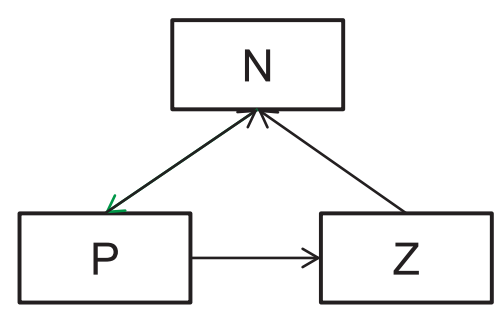

c) SS type

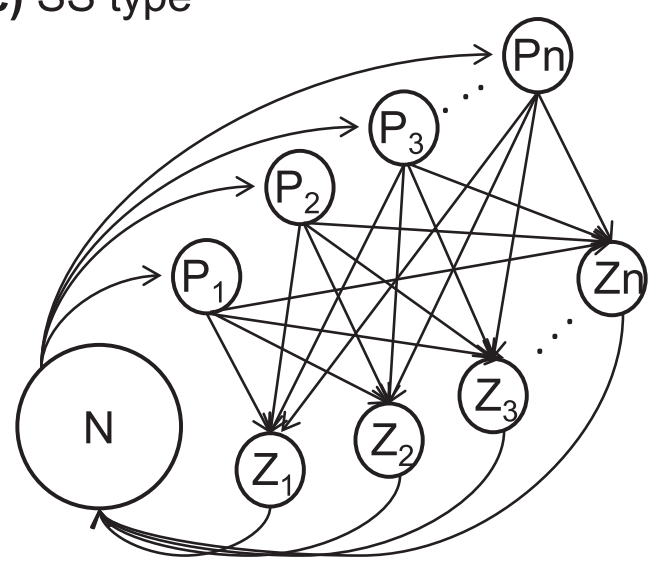

b) NPZD type

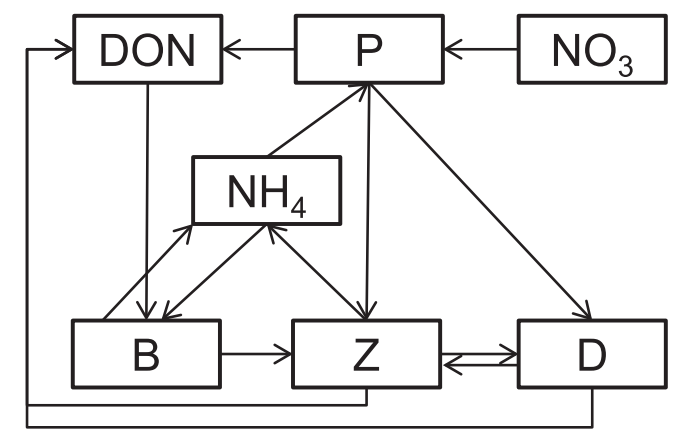

d) PFT type

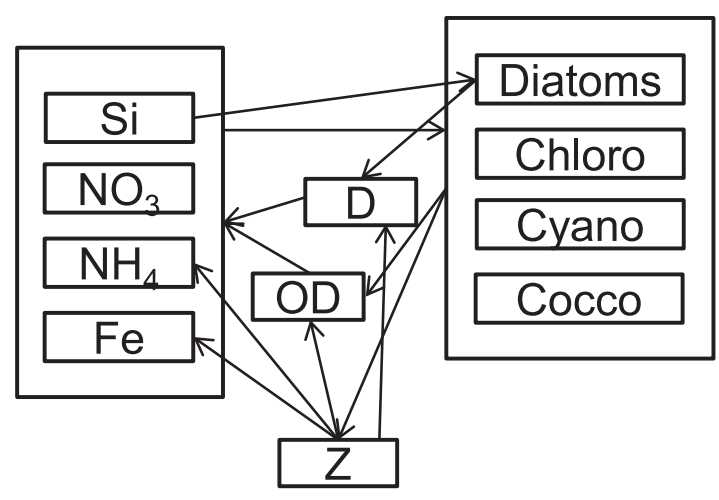

Figure 1 - Types of planktonic trophic models in order of increasing complexity. a) NPZ model; b) NPZD model by Fasham et al. (1990); c) SS model by Banas (2011); d) PFT model by Gregg et al. (2003). N-nutrient; P-phytoplankton; Z-zooplankton; DONdissolved organic nitrogen; B-bacteria; D-detritus; $\mathrm{P}_{1-\mathrm{n}}$ : phytoplankton of different sizes; $\mathrm{Z}_{1-\mathrm{n}}$ : zooplankton of different sizes; ODorganic detritus; Chloro-chlorophycean; Cyano-cyanophycean; Cocco-coccolithophorid.

\section{TRANSFER FUNCTIONS}

There are three transfer functions that are common to any planktonic trophic model: nutrient uptake by phytoplankton, zooplankton grazing, and zooplankton mortality (commonly referenced in the literature as 
'closure term'). They can be built with simple functional forms (e.g., Michaelis-Menten and Holling types) or with more complex ones (e.g., as observed on eco-physiological models) (Table I).

TABLE I

Functional forms most commonly used in the literature and more complex alternatives to describe three transfer functions: phytoplankton nutrient uptake, zooplankton grazing, and zooplankton mortality (closure term).

Transfer Function

Phytoplankton Nutrient Uptake

Zooplankton Grazing

$$
\begin{gathered}
a \cdot P \\
\frac{a \cdot P}{1+a \cdot h \cdot P} \\
\frac{I_{\max } \cdot P}{k_{1}+P} \\
\frac{a \cdot P^{2}}{1+a \cdot h \cdot P^{2}} \\
\frac{I_{\max } \cdot P^{2}}{k_{1}^{2} \cdot P^{2}} \\
\frac{a_{i} \cdot P_{i}}{1+\sum_{1}^{n} a_{r} \cdot h_{r} \cdot P_{r}}
\end{gathered}
$$$$
\frac{V_{\max } \cdot N}{k+N}
$$$$
\mu_{\max } \frac{1-\frac{Q_{\text {min }}}{Q}}{1-\frac{Q_{\text {min }}}{Q_{\text {max }}}}
$$$$
\mu_{\max } \frac{Q-Q_{\min }}{\left(Q-Q_{\min }\right)+K}
$$$$
\mu_{\max } \frac{(1+K Q) \cdot\left(Q-Q_{\text {min }}\right)}{\left(Q-Q_{\text {min }}\right)+K Q \cdot\left(Q_{\text {max }}-Q_{\text {min }}\right)}
$$

Quota Curve; rectangularhyperbolic

Caperon and Meyer 1972

Normalized Quota equation; rectangular-hyperbolic

Type I; quadratic

Holling 1959

Type II; hyperbolic

Holling 1959

Monod / Michaelis-Menten; hyperbolic

Type III; sigmoidal

Holling 1959

Monod or Michaelis-Menten; sigmoidal

Type II; hyperbolic; multiple prey items

Gentleman et al. 2003

where $n$ is prey number

$$
\begin{gathered}
\frac{I_{\max } \cdot \sum C_{p i}}{k_{1}+\sum C_{p i}}, \\
\text { where }_{p i}=C_{r i} \cdot P_{i}
\end{gathered}
$$

Monod; hyperbolic; prey selectivity

Mitra and Flynn 2006 
TABLE I (continuation)

\begin{tabular}{lccc}
\hline Transfer Function & Functional Form* & Description & Reference \\
\hline $\begin{array}{l}\text { Zooplankton mortality } \\
\text { closure term) }\end{array}$ & $m \cdot Z$ & Quadratic & Mitra 2009 \\
& $\frac{m \cdot Z}{k_{2}+Z}$ & Hyperbolic & Mitra 2009 \\
$\frac{m \cdot Z^{2}}{k_{2}^{2}+Z^{2}}$ & Sigmoidal & Mitra 2009 \\
$\frac{m \cdot Z \cdot c}{k_{2}+Z \cdot c}$ & Hypebolic; intraguild predation & Mitra 2009
\end{tabular}

$* \mathrm{~V}_{\max }=$ maximum nutrient uptake rate; $\mathrm{N}=$ nutrient availability; $\mathrm{k}=$ half-saturation constant for nutrient uptake; $\mu$ max $=$ maximum growth rate; $\mathrm{Q}_{\min }=$ minimum nutrient quota; $\mathrm{Q}=$ nutrient quota; $\mathrm{Q}_{\max }=$ maximum nutrient quota; $\mathrm{K}=$ half-saturation constant for quota curve; $\mathrm{KQ}=$ dimensionless half-saturation constant for the normalized quota curve; $\mathrm{a}=$ attack rate; $\mathrm{P}=$ phytoplankton availability; $\mathrm{h}=$ handling time; $\mathrm{I}_{\max }=$ maximum ingestion rate; $\mathrm{k}_{1}=$ half-saturation constant for ingestion; $\mathrm{i}=$ subscript for prey type; $\mathrm{r}=$ subscript relative to prey type weight; $\mathrm{C}_{\mathrm{pi}}=$ potential capture rate; $\mathrm{C}_{\mathrm{ri}}=$ capture rate; $\mathrm{m}=$ zooplankton mortality rate; $\mathrm{Z}=$ zooplankton availability; $\mathrm{k}_{2}$ = half-saturation constant for zooplankton closure term; $\mathrm{c}=$ fraction of zooplankton on which closure term acts.

Nutrient uptake by phytoplankton is typically described using Monod (Monod 1942) or MichaelisMenten equations (both present the same functional form), which can be used to describe phytoplankton growth in relation to the concentration of a limiting nutrient. A common, more flexible alternative is the Quota model (Droop 1968), which describes phytoplankton growth as a function of the internal nutrient concentration. The Quota model may be represented in various ways, ranging from linear to hyperbolic behaviors.

In general, models that account for multi-nutrient limitation, such as modified versions of the Quota model, and for acclimation-related processes have more predictive power (Flynn 2001, Cherif and Loreau 2010, Bonachela et al. 2011). Such models adjust the kinetic parameters (e.g., maximum uptake rate and half-saturation constant) according to factors such as the cell response to light/dark cycles and other environmental changes (Flynn 2001, Cherif and Loreau 2010, Bonachela et al. 2011). Such approaches are known as eco-physiological models (e.g., mechanistic approaches) and differ from the simpler functional forms because they are based on the current biological understanding of the individual or functional groups included in the models. As a result, eco-physiological models typically feature an increased number of parameters that are not found in the literature or easily obtained experimentally. Complex experiments, such as those investigating the effect of multiple variables on nutrient uptake, may help to determine such parameters.

The functional response of zooplankton (ingestion as a function of prey density) is usually represented by simple functional forms, as described by Holling (1959): Type I (linear function), which does not account for satiation; Type II (rectangular hyperbolic function), such as Monod type, which accounts for satiation; and Type III, which accounts not only for satiation but also for learning time and prey switching at low prey density (sigmoidal function). Model output varies greatly according to the functional form used to describe grazing: Type II has a destabilizing effect on model output, inducing high oscillations of the state 
variables over time; Type III stabilizes the system, such that the steady state is easily achieved; and Type I has no influence on model stability. Such behaviors are assumed to be related to the density-dependence of clearance rates rather than depending on satiation or non-satiation conditions (for details, see Gentleman and Neuheimer 2008).

With respect to ingestion, the description of assimilation efficiency is usually oversimplified, considered a fixed proportion of the ingested material. More complex configurations (e.g., eco-physiological models) that take into account the effect of prey selectivity and quality, and gut satiation on ingestion, as well as assimilation efficiency, better represent the zooplankton compartment (Mitra and Flynn 2006, Mitra et al. 2007, Montagnes and Fenton 2012) (Table I). In addition, zooplankton grazing also varies according to temperature, turbulence, and prey size (Saiz 1994, Seel et al. 2001, Viherluoto and Viitasalo 2001, Richardson 2008); these factors should be considered when modelling zooplankton dynamics.

Plankton models are also highly sensitive to the closure term, which relates to the predation on zooplankton by organisms not included in the model. For example, if described by a linear function, there would be oscillations in the predator-prey cycle, while stabilization of the system would be achieved via quadratic function (Steele and Henderson 1992). The closure term is typically related to higher trophic levels (i.e., fish) that are not explicitly included on the model; nonetheless, most zooplankton losses are related to predation by other zooplankton species, cannibalism, and intraguild predation. For example, copepods are the preferential prey for chaetognaths and siphonophores (Saito and Kiørboe 2001, Hirst et al. 2007), and research indicates that cannibalism is an alternative when preferential food is scarce (Stuart and Verheye 1991, Gismervik and Andersen 1997). Despite being a major contributor to zooplankton losses, intraguild predation, the predation between potentially competing species such as microzooplankton and copepods (Ptacnik et al. 2004), is usually neglected on plankton models (Mitra 2009).

After important aspects of plankton modelling have been clarified, we address plankton model studies from the literature. In doing so, we focus on whether model complexity has increased over the 15 years and the degree to which the level of complexity relates to research area. We also assess the steps used for testing model performance and the degree to which that relates to model complexity.

\section{MATERIALS AND METHODS}

For the literature review, two electronic databases (ISI Web of Science and 'ScienceDirect') were used to access all studies employing plankton models published in indexed journals between 2000 and May 2014. The following keywords were used: "NPZ model", "NPZD model", "PFT model", "plankton model", and "marine size resolved model". Ecosystem models were not included in this review because such models focus on higher trophic levels. In total, 137 articles comprising 145 models were selected for analysis (see Table SI - Supplementary Material). Models were classified into NPZ (nutrients, phytoplankton and zooplankton), NPZD (NPZ + bacteria, detritus and/or different forms of nitrogen), SS (based on plankton size) and PFT (multiple functional groups) based on the type and number of state variables, as detailed below.

Based on this classification, we evaluated model application (theoretical, heuristic or predictive), model approach (biological, physical-biological or biogeochemical), model robustness (sensitivity analysis, calibration and validation), and global application of planktonic trophic models (with focus on the current situation in Brazil).

We evaluated the contexts in which models were applied, according to the classification of Franks (2002): theoretical, heuristic, or predictive. Theoretical models are used from a mathematical point of view 
(e.g., to analyze model behavior due to changes in parameter values and functional forms) and as a tool for hypothesis testing. Heuristic models reproduce in situ observations in order to investigate system dynamics, and, in general, have previously been investigated theoretically. As their name implies, predictive models aim to predict biological dynamics. Predictions are only possible after theoretical exploration of the model and validation (see validation below).

Models were also evaluated according to their approach. One approach, biological, is interested in biological and ecological interactions within the plankton. The physical-biological approach adds to the biological approach an investigation of the influences of physical processes on plankton dynamics. The third approach, biogeochemical, focuses on biogeochemical cycles.

In theory, all models should undergo three critical analyses: sensitivity analysis, calibration, and validation (Jorgensen 1994). In practice, however, these analyses are not always conducted. To assess the robustness of planktonic trophic models, the presence or absence of each step was evaluated in modelling studies that compared model output with observed data (a total of 84 models).

Sensitivity analysis, recommended as the first step in building a model, involves testing different values for the parameters and state variables, and testing different functional forms to assess their influence on model output. On this manner, it is possible to identify the parameters that exert the greatest influence on model output (and therefore must be accurately estimated) and those that do not exert greater influence on the model (and therefore may be not essential descriptors). For the present analysis of sensitivity, we evaluated the models based on two categories: partial sensitivity (only some elements of the model undergo analysis) and total sensitivity (all elements of the model undergo analysis).

Calibration, considered the second modelling step, interacts with sensitivity analysis. Before conducting the sensitivity analysis, the range of values that a parameter can be assigned must be obtained from the literature; this is already part of model calibration. It is vitally important that realistic values are used for the simulations otherwise the underlying processes may be misinterpreted. After defining the set of parameter values, the sensitivity analysis is conducted. The most sensible parameters can be recalibrated by modifying their values; for models with a large number of parameters, optimization techniques can be used. Optimization techniques are based on the assimilation of empirical data into the model in order to determine the parameter values that provide the best fit between model output and observed data (e.g., Garcia-Gorriz et al. 2003). Then, a new sensitivity analysis can be conducted, and the process is repeated as many times as necessary. In this study, calibration took into account the use of realistic parameter values (rather than arbitrary values) and the use of optimization techniques.

Validation, the third step, serves to verify the accuracy of the model testing whether it is satisfactory (Jorgensen 1994). The most common method for validating a model is to test it against independent data that is different from the data used to calibrate the model and preferentially represents different conditions of the system. For appropriate validation, it is also recommended to test model predictions in regions similar to the original model, to verify whether the biological rates provided by the model are realistic compared to values found in the literature, and to apply statistical measures (e.g., calculation of the mean absolute error and use of statistical tests such as the t-test and regression analysis) in order to assess the fit between simulated and observed data (Stow et al. 2009). In this survey of the literature, plankton models that used only independent data in the validation process were considered to have performed partial validation; models that used addition validation methods were classified as having conducted total validation. 


\section{RESULTS AND DISCUSSION}

\section{MODEL COMPLEXITY OVER TIME}

Of the 145 models published from 2000 to 2014, 34\% were classified as PFT, 32\% as NPZ, 23\% as NPZD, and $11 \%$ as SS models. Articles published from 2000 to 2006 comprised mostly NPZ and NPZD models (Fig. 2). The first SS models parameterized by allometric relationships appeared in 2005. The number of PFT models surpassed that of NPZD models in 2009 and remained higher, even surpassing the number of NPZ models in 2013 (Fig. 2).

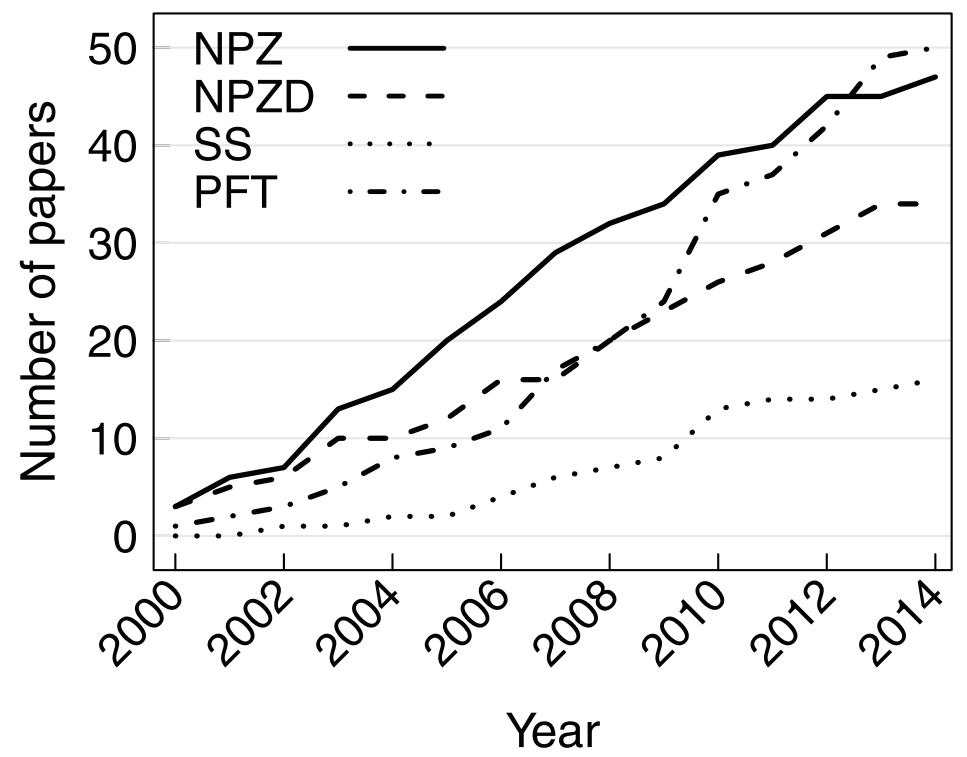

Figure 2 - Cumulative number of articles about planktonic trophic models published from 2000 to May 2014 for each type of model (NPZ, NPZD, SS, and PFT). Figure preparation was carried out using R software (R Core Team 2016).

As expected, the results presented here indicate that more complex models (PFT) are becoming as common in the literature as NPZ models. It is likely that SS models were not as common as PFT models not only because they constitute a more recent approach but also because PFT models accomplish what characterizes SS models; that is, PFT models may consider plankton size when defining planktonic functional groups. Considering the interest in understanding oceans in the context of climate change, PFT models have been developed to enable investigation of biogeochemical questions (e.g., Gregg et al. 2003, Follows et al. 2007, Moore et al. 2004, Le Quéré et al. 2005, Anderson et al. 2010); as a result, application of these models has increased over time. The increased use of PFT models may be also due to the acknowledgment of the physiological and ecological complexity of planktonic cells/organisms, supporting separation into more than two functional groups.

However, models with fewer state variables continue to be used (Garcia-Gorriz et al. 2003, Lewis 2005, Macías et al. 2007, Hernández-Carrasco et al. 2014), especially when more than one field is approached (e.g., biological + physical oceanography). Such models are most commonly used to investigate plankton response to factors such as upwelling systems driven by wind (Edwards et al. 2000), Langmuir circulation 
in a turbulent mixing layer (Lewis 2005), and high-frequency internal waves (Lai et al. 2010). In addition, the use of simpler models serves as an alternative when there is little information available on the system being investigated (e.g., a lack of empirical data such as rates and plankton biomass). Efforts to increase the amount of information about plankton species can provide the basis for the increased use of models with more compartments or state variables.

Regarding the functional forms used to build the planktonic trophic models, we found that $43 \%$ of the models were based on simple functional forms, while $11 \%$ were based on mechanistic approaches (and, therefore, more complex functional forms). The remaining $46 \%$ of the models were considered 'semimechanistic' because each featured a mix of simpler and more complex functions. Mechanistic approaches were found across all model types, but were more frequent in SS models (NPZ $=10 \%$; NPZD $=6 \%$; SS = $18 \%$; PFT $=12 \%$ ); simple functions occurred most frequently in NPZ models (NPZ $=71 \%$; NPZD = 58\%; $\mathrm{SS}=23 \%$; PFT $=23 \%$ ). PFT was the model type that most commonly appeared in the 'semi-mechanistic' category $(\mathrm{NPZ}=19 \%$; NPZD $=36 \%$; SS $=59 \%$; PFT $=65 \%)$.

Several trends were evident within the above data. First, Michaelis-Menten kinetics for nutrient uptake by phytoplankton was the most common, appearing in nearly $50 \%$ of plankton models despite the fundamental issues related to it (Franks 2009). The remainder of the plankton models could be categorized as 'semi-mechanistic', since they keep certain descriptions simple and others more complex, based on the current biological understanding of the process (e.g., Baird and Suthers 2007). As plankton food webs are quite complex, it is difficult to use a faithful mechanistic approach when modelling (Flynn et al. 2015), such that mixed approaches were more common.

Second, the investment in model complexity was greater in the nutrient-phytoplankton coupling, despite the reasonable number of mechanistic models developed for zooplankton in the last 10 years (Mitra et al. 2014a). As a consequence, the zooplankton compartment often ends up being "sacrificed" in favor of other model variables. A possible solution to avoid such unbalanced levels of complexity across variables is to develop a complex model and then carefully reduce its complexity through the identification of processes that do not significantly affect model output. This process should be conducted in accordance with the objective of the model (i.e., the scientific question being addressed).

Third, we observed that many models achieved complexity by increasing the number of state variables (i.e., using PFT type) and using complex functions (40 models out of 52 PFT models); in contrast, most of the models that considered few state variables (i.e., NPZ type) also used simple functional forms (29 models out of $41 \mathrm{NPZ}$ models). Both model types (NPZ and PFT) should aim to increase the complexity of functional forms. Indeed, due to the reduced complexity in the number of state variables, NPZ models provide a friendlier platform to incorporate feedback processes and, therefore, more complex functional forms.

The selection of functional form is very important for model performance. In particular, modelers must bear in mind that the choice of state variables and functional forms are determined, to a great degree, by the question that the model intends to answer, rather than merely providing maximal simplicity and/or lowest computational costs.

MODEL APPLICATION AND APPROACH

Most plankton models comprised theoretical (45.5\%) or heuristic (49\%) approaches; only 5.5\% of the models were predictive (Fig. 3). Theoretical models comprised statistical studies to improve the sensitivity 
analysis of parameter values (e.g., Arhonditsis et al. 2008, Chu et al. 2007, Roy et al. 2012), studies that evaluated the sensitivity of model output to different functional forms (e.g., Bonachela et al. 2011, Gentleman et al. 2003, Mitra 2009), and hypothesis-driven studies (e.g., Stickney et al. 2000). Heuristic models performed qualitative comparisons between observed and simulated data, as well as quantitative comparisons verifying biomass values, biological rates, and other parameters. Examples include the NPZ model used by Botsford et al. (2003) in order to clarify the influence of wind on primary productivity in an upwelling system, and the PFT model by Moore et al. (2004) that investigated plankton influence on the iron cycle. Only eight predictive models were found in the literature $(\mathrm{NPZ}=3, \mathrm{PFT}=3, \mathrm{NPZD}=1, \mathrm{SS}=$ 1); and more complex, PFT models were applied for predictions. In keeping with the scenario of climate change in the oceans, model predictions mainly relate to the impact of climate change on plankton (e.g., the effect of ocean acidification; Pierce 2004, Yool et al. 2013) and its consequences at higher trophic levels (Megrey et al. 2007, Steele and Gifford 2010).

Most PFT and SS models were theoretical, whereas most NPZ and NPZD models were heuristic (Fig. 3). This finding may relate to the fact that the accuracy of PFT and SS models remain to be demonstrated fully (Aber 1997), whereas NPZ and NPZD models have been well established in the literature since the 1990s. In addition, there is a better availability of empirical data to meet the requirements of NPZ models compared with SS and PFT models. In the review by Franks (2002), no NPZ model with predictive application had been found, and over a decade later, this scenario does not seem to have changed much, as only three predictive NPZ models were found in this review. Predictive models play an important role in decisions related to ecosystem management, particularly those concerning rapid changes in the marine systems. Despite their importance, as well as the apparent availability of empirical data, predictive models remain rare in the literature.

More than half of the models analyzed were classified as biological (Fig. 3b); given that physical and chemical aspects often occur as additions to biological models, it is expected that models are most often explored initially at the biological level. NPZ models comprised most of the models classified as physical-biological (46\%), probably because NPZ models provide such robust results for oceanographic research (Franks 2002). Indeed, it is not always worthwhile to increase model complexity by coupling the physical model to PFT or SS configurations if the NPZ configuration satisfies model requirements,
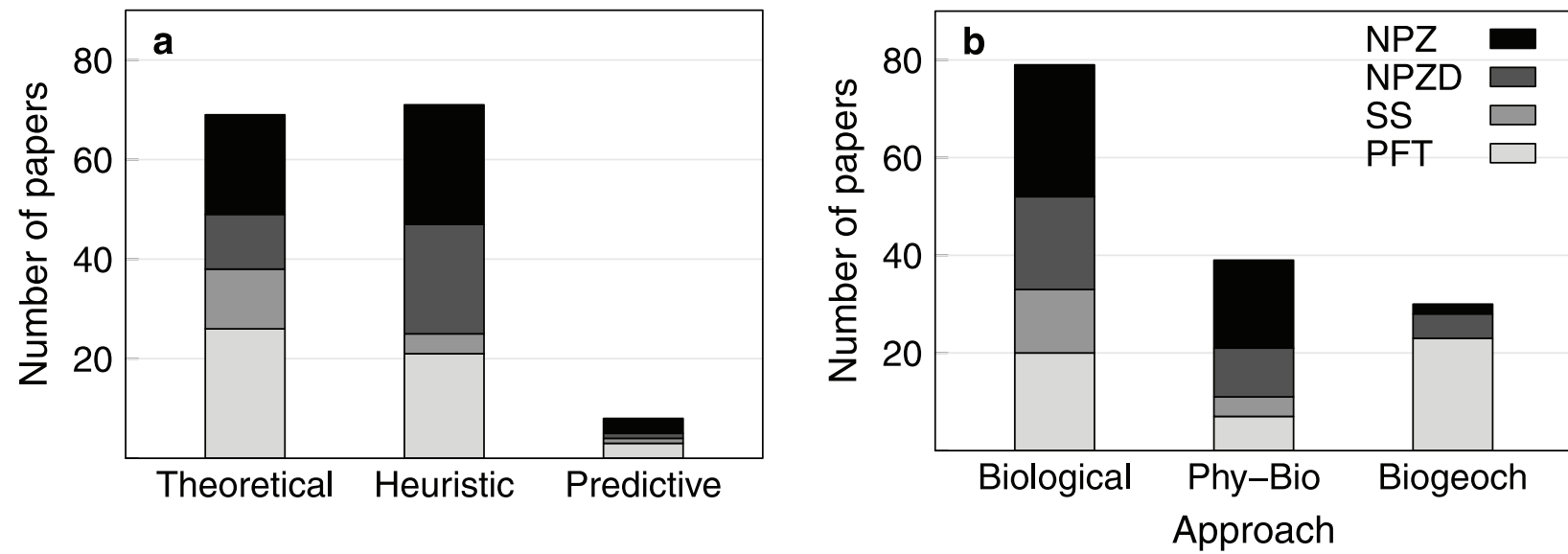

Figure 3 - Purpose of planktonic trophic models (NPZ, NPZD, SS, and PFT): a) model application: theoretical, heuristic, or predictive; b) model approach: biological only, physical-biological (Phy-Bio), or biogeochemical (Biogeoch). Figure preparation was carried out using R software (R Core Team 2016). 
especially considering that the physical model already carries a large number of parameters and a substantial computational cost. For the biogeochemical approach, PFT models were most common (77\%), as it is necessary to describe the different plankton functional types according to their roles within biogeochemical cycles.

The choice between simple and complex models depends primarily on the scientific question to be answered. NPZ models and simple functional forms have been successfully used to determine primary productivity as a function of light, nutrient availability, and predation (e.g., Dube and Jayaraman 2008, Brandt and Wirtz 2010) and to investigate the influence of physical processes on plankton dynamics (e.g., Botsford et al. 2003, Banas et al. 2009, Lai et al. 2010). Because it has few state variables and parameters, the NPZ model is more easily analyzed and coupled to a physical model. However, biological or physical-biological models can lack information. Further, grouping all planktonic species into the phyto- and zooplankton compartments may not be appropriate for certain approaches, such as modelling biogeochemical cycles, which are usually based on PFT models. In these models, phyto- and zooplankton are subdivided according to plankton size and biogeochemical role (e.g., coccolithophorids, diatoms, nitrogen fixers, microzooplankton, mesozooplankton) (Gregg et al. 2003, Moore et al. 2004, Le Quéré et al. 2005) and more complex functional forms are usually implemented, as discussed above (e.g., Follows et al. 2007, Perhar et al. 2013, Mitra et al. 2014a).

Although modelers agree that there is a need to increase model complexity (Blackford et al. 2010), there is debate over how the accuracy of models varies with complexity (Anderson 2005, Flynn 2005, Le Quéré 2006). Greater complexity comes at the cost of increasing the number of state variables and parameters. However, knowledge concerning different functional groups is not yet sufficient to fit all model parameters, making it difficult to test model accuracy and bringing to mind the notion that we are "running before we can walk" (Anderson 2005). In the next section, we evaluated the effort of modelling studies to test model performance, and how that relates to model complexity.

HOW ROBUST ARE THE MARINE PLANKTONIC TROPHIC MODELS?

For each of the four models, over $75 \%$ of studies conducted sensitivity analysis. However, only 17 - 38\% conducted total sensitivity analysis, depending on model type; the occurrence of total sensitivity analysis was particularly high for PFT models (Fig. 4a). The task of identifying the parameters to which the model is sensitive is most difficult for PFT models due to the high number of parameters, and thus, it is even more necessary. Almost all plankton models (77 out of 84) obtained parameter values from the literature. Optimization techniques were most often used in NPZD models with more than 5 state variables ( $40 \%$ of such models) and in PFT models ( $\sim 20 \%)$, reflecting that models with a high number of parameters simply do not work well if not previously calibrated (Fig. 4b). In contrast, SS models had a lower incidence of calibration, probably because many of these models were parameterized via allometric relationships that reduced the total number of parameters. The results regarding validation were similar for all groups, with less than $20 \%$ of models totally validated (Fig. $4 \mathrm{c}$ ).

Although sensitivity analysis should be a recurrent measure of model robustness, many studies ( $\sim 25 \%)$ ignored it. In addition, most sensitivity analyses relied only on the parameter values, rather than also analyzing the choice of the functional forms, which may drastically alter model output (as discussed in the section "Transfer Functions"). Most models checked the parameter values in the literature, and more than $40 \%$ applied optimization techniques. Evans (2003) demonstrated that these techniques can have a 

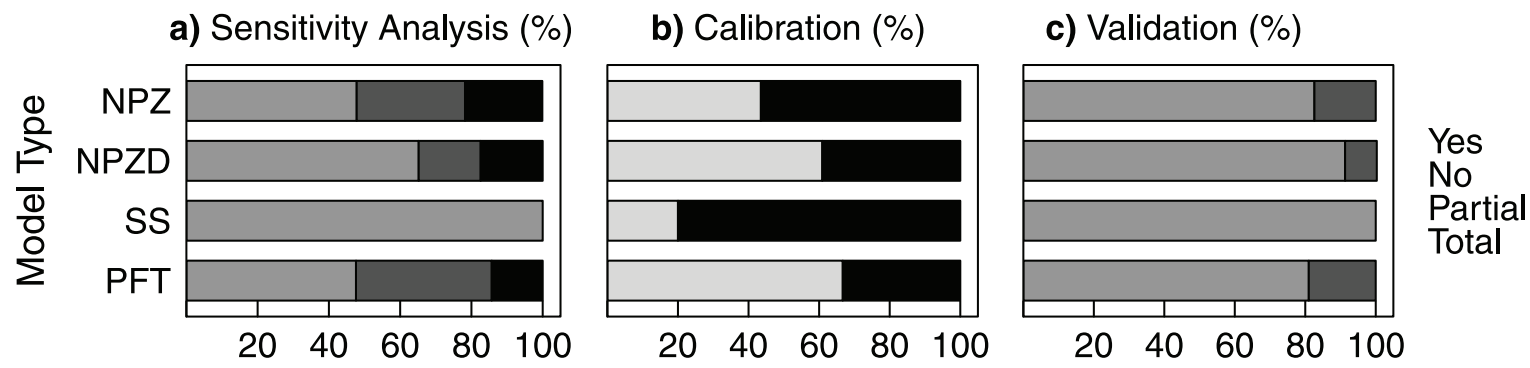

Figure 4 - Proportion of planktonic trophic models that: a) performed sensitivity analysis (partial-applied to some model elements; total-all model elements undergo analysis); b) used optimization techniques for calibration; and c) conducted validation (partialcompared simulated data with observed data; total-partial plus: applied the model to other regions and/or verified if the simulated biological rates were realistic and/or used statistical metrics to assess the fit between simulated and observed data). Only models that compared simulated and observed data were included on this analysis (NPZ, $n=23$; NPZD, $n=25$; SS, $n=6$; and PFT, $n=$ 40). Figure preparation was carried out using R software (R Core Team 2016).

large influence on model output in biogeochemical models and should therefore be performed carefully, especially considering that the data set is only a snapshot of the system to be modeled and may differ from other conditions (Evans 2003, Chu et al. 2007, Zhao and Lu 2008, Roy et al. 2012). Modelers should also be careful if unrealistic parameter values are assigned after conducting optimization techniques, possibly resulting in a good fit for the wrong reasons (Anderson 2005, Ward et al. 2010). Instead of looking only for the best fit (e.g., Zhao and Lu 2008, Roy et al. 2012), statistical investigations aiming to identify and quantify model uncertainties may be more appropriate and increase the robustness of models (Arhonditsis et al. 2008). Overall, there is a clear need for more experiments that empirically describe the parameter values needed for building plankton models. It seems that there is a disconnect between experimental and modelling research: "we do not model what we measure, and we do not measure what we model" (Franks 2009). This is also true for validation, since it is based on existing and independent data sets which, when available, are not always adequate for model validation. To address this issue, there is a need to improve the dialogue among field researchers, experimental researchers, and modelers (Flynn 2005).

\section{PlANKTONIC TROPHIC MOdELS AROUND THE GLOBE}

Most plankton models were applied in locations within the Northern Hemisphere (74 models in the Northern Hemisphere compared to only nine in the Southern Hemisphere), with most occurring on the west and east coast of the United States, the North Sea, Baltic Sea, and the Mediterranean Sea. NPZ and NPZD models (coupled with physical representation) were the ones most commonly applied on the American coasts, whereas biogeochemical models (i.e., PFT models) were most common on the European coast. Some models have also been applied in the Arabian Sea (PFT models) and in China and Japan (mainly NPZ and NPZD) (Fig. 5).

Two regional models were observed in the Southern Hemisphere: one was located on the west coast of Africa and investigated the influence of Benguela Current on plankton dynamics, while the other was used on the Antarctic Peninsula in order to understand the role of light and grazing in both sequestration of atmospheric $\mathrm{CO}_{2}$ and food availability to larval krill. Six models were applied in the Southern Hemisphere at the ocean-basin scale and one in the high-nutrient-low-chlorophyll (HNLC) regions in Antarctic. No plankton model was applied in the Brazilian coast during the last 15 years.

There is a lack of experimental and modelling studies in planktonic food webs in the Southern Hemisphere, including Brazil (Fig. 5). In the pre-2000 literature, there is only a single record of a trophic 


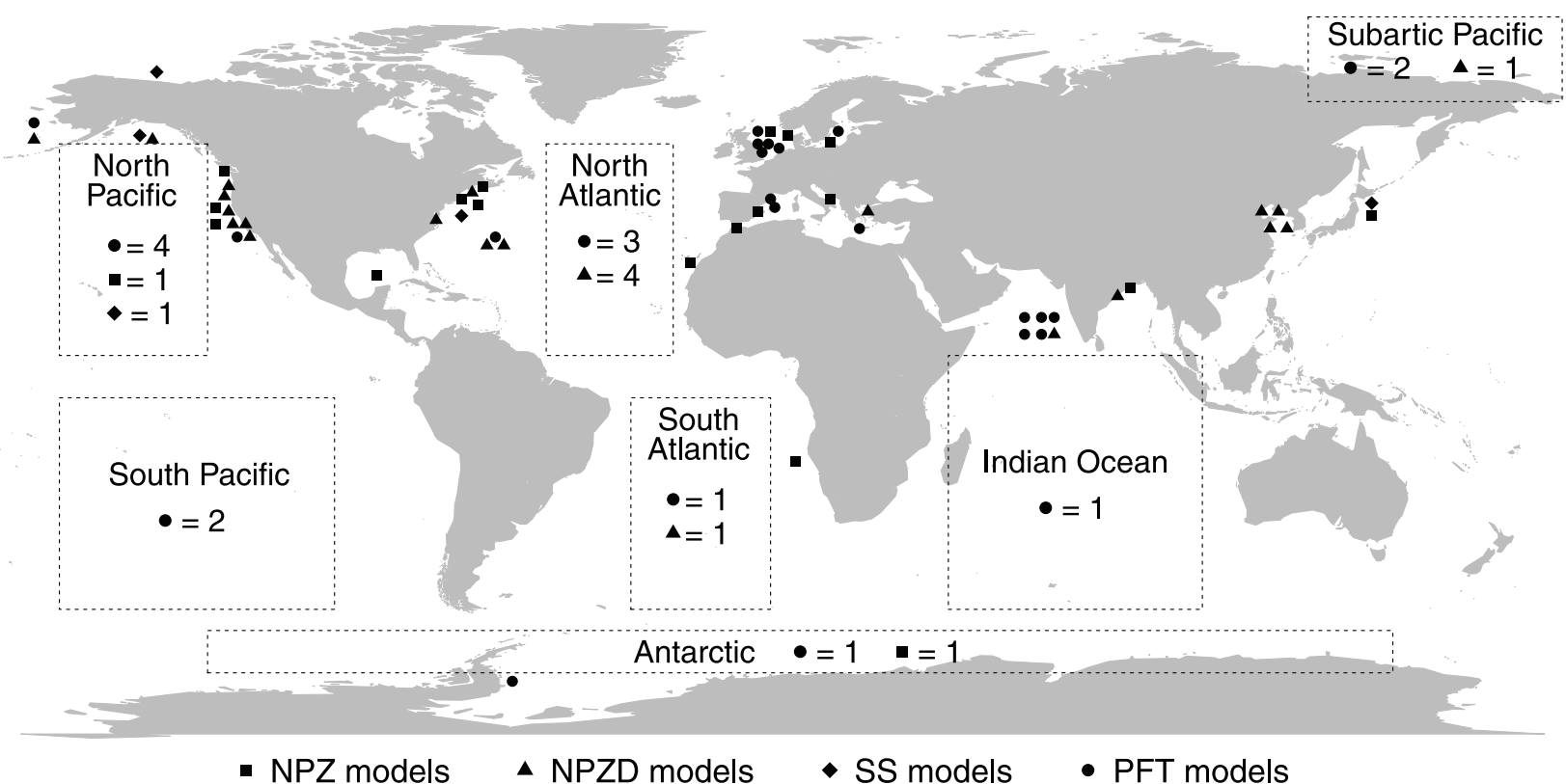

Figure 5 - Spatial distribution of planktonic trophic models. Isolated symbols represent regional scale models and dashed lines correspond to ocean-basin scale models. Number of global scale models is as: NPZ $=0$; NPZD $=3$; $\mathrm{SS}=0$; and PFT $=11$. Figure preparation was carried out using the $\mathrm{R}$ package maps ( $\mathrm{R}$ Core Team 2016).

model being applied in Brazil, a physical-biological NPZ model that simulated the phytoplankton bloom in the Cabo Frio (Rio de Janeiro) upwelling system (Carbonel and Valentin 1999). When all planktonic models, and not exclusively trophic models, were included in the search for Brazil, only one model applied in the marine system was found (Valentin and Coutinho 1990), while ten models applied in lakes and reservoirs were found (e.g., Araújo et al. 2008, Fragoso et al. 2008, Fernández et al. 2012, Deus et al. 2013). Deus et al. (2013), for example, investigated spatial and temporal phytoplankton patterns in the Tucuruí reservoir (Pará) using a robust NPZD platform coupled with a 3D physical model and performing all three of the modelling steps described above (i.e., sensitivity analysis, calibration and validation).

There are several factors that may explain why more models were found for freshwater systems than for marine systems in Brazilian studies. First, the development of models for freshwater systems requires less complexity because lakes and reservoirs are spatially bounded systems (i.e., closed systems), which makes it easier to understand how the system functions. Second, concern for the water quality in Brazilian reservoirs has led to an increased effort to develop models that represent multiple nutrient and specific phytoplankton functional groups. In addition, the costs associated with sampling programs in freshwater systems are lower than those associated with marine areas.

Compared to plankton models, ecosystem modelling (end-to-end models) has been more frequently applied in Brazil (e.g., Angelini and Petrere 2000, Wolff et al. 2000, Angelini et al. 2006, Rocha et al. 2007, Freire et al. 2008, Fulton 2010). The ECOPATH software (based on Polovina 1984), which is generally used to build these models, is a static model that estimates biomass and the consumption of different components of an aquatic ecosystem based on network theory, and may be extended into a dynamic and/ or spatial model. Because ECOPATH initially focused on simulating fish stocks, it features a lower level of detail for planktonic compartments compared to the planktonic trophic models discussed throughout this review. The importance of better detailing the planktonic system (especially zooplankton) within end-to- 
end models has been discussed in the literature but remains underappreciated (Mitra et al. 2014b).Thus, there is a need to incorporate greater detail, as provided by planktonic trophic models, into ECOPATH and other ecosystem models.

To better understand ecosystem functioning and make ecological predictions, it is important to understand the base of the food web, which is made up of plankton. Although there have been a reasonable number of field studies on plankton within Brazil, they have been restricted to examining only planktonic diversity and density. In comparison, studies addressing planktonic biomass and biological rates, whether experimental or in the field, remain rare, reflecting the lack of development in plankton modelling. There is an urgent need for studies that estimate biological rates (e.g., nutrient uptake and ingestion rates), quantify the biomass of different planktonic compartments (including the mixotrophs and their trophic function), identify new interactions (e.g., viruses as infectious), and examine known interactions (e.g., intraguild predation between copepods and microzooplankton). In light of marine ecosystems changes related to eutrophication, acidification, pollution, and warming, more effort should be made to develop research programs on modelling planktonic systems in Brazil, an essential tool for the management plans for coastal ecosystems.

\section{CONCLUSIONS}

This study aimed to address the question of whether NPZ models are too simplistic, and if more complex models (e.g., PFT) may provide more realistic predictions. There may be no definitive answer to this question, simply because model complexity depends so heavily on the nature of the scientific question at hand. Nonetheless, we consider that our analysis has revealed some trends related to model complexity that may help researchers to understand how to best apply simple and complex models.

First, analysis revealed an urgent need to open the compartments of phytoplankton and zooplankton, particularly when dealing with biogeochemical cycles and plankton food web dynamics. In fact, more PFT models than NPZ and NPZD models were used for such studies during the period assessed. On the other hand, NPZ and NPZD models are considered satisfactory when the focus of the model is physical oceanography. Although the number of state variables depends on the question being asked, studies should always aim to include more complex functional forms; otherwise, insufficient description of important aspects of phyto- and zooplankton physiology can lead to misinterpretation of model results. However, half of the models analyzed here were based on simple functional forms, particularly NPZ models. We suggest that mechanistic approaches (e.g., eco-physiological models), which have been employed by some studies, represent the best way forward for modelling plankton dynamics.

Importantly, we observed that many studies did not accomplish all of the steps suggested for modelling. There are several possible reasons for this shortcoming, including a failure to recognize the importance of testing different functional forms when modelling plankton dynamics. Other possible contributors include a lack of empirical data, particularly experimental studies that measure biological rates, and a lack of dialogue between field and modeler researchers, resulting in poor data sets for use in model validation. As a consequence, it is difficult to demonstrate the robustness of existing models; new techniques, such as the optimization of parameter values that are not known in the literature, are being developed to overcome this problem. Although such techniques are useful, they should be used with caution; the best solution to this problem is an increased effort to obtain the right type of data. 
Finally, we indicated which regions of the globe need to develop studies in plankton modelling urgently. While plankton models are used throughout the Northern Hemisphere, they are scarce in the Southern Hemisphere, including Brazil. Without doubt, a major contributor to this lack of modelling studies is a lack of empirical data (e.g., biological rates, plankton biomass in terms of carbon), especially in marine systems. We determined that the best route to improve plankton modelling in Brazil and around the globe is through multidisciplinary research and the implementation of more complex models, especially regarding the description of plankton physiology.

\section{ACKNOWLEDGMENTS}

We thank Dr. Reinaldo Bozelli, Dr. Helena Passeri and two anonymous reviewers who made valuable comments for this manuscript. Suzana Leles had a fellowship from Coordenação de Aperfeiçoamento de Pessoal de Nível Superior (CAPES) through the post-graduation program of Ecology from the Federal University of Rio de Janeiro.

\section{RESUMO}

Os modelos planctônicos compreendem uma ferramenta valiosa para criar hipóteses e realizar predições quanto ao funcionamento dos ecossistemas marinhos. A complexidade destes modelos varia de acordo com o número de variáveis de estado e com a escolha de formas funcionais utilizadas. Nós avaliamos os modelos planctônicos durante os últimos 15 anos $(\mathrm{n}=145)$ a fim de compreender porque eles variam em complexidade, avaliando a robustez dos modelos e descrevendo os estudos de modelagem do plâncton ao redor do globo. Nós classificamos os modelos em quatro grupos: Nutriente-Fitoplâncton-Zooplâncton (NPZ), Nutriente-Fitoplâncton-Zooplâncton-Detritos (NPZD), Estruturado pelo tamanho (SS) e Tipo Funcional Planctônico (PFT). Nossos resultados revelaram que o número de variáveis de estado variou de acordo com a pergunta do modelo; modelos NPZ foram mais frequentemente aplicados em estudos físico-biológicos enquanto que modelos PFT foram os mais utilizados para investigar ciclos biogeoquímicos. A maioria dos modelos se baseou em formas funcionais simples que omitiram 'feedbacks' importantes relacionados à dinâmica de controle populacional do plâncton. Algumas vezes, estudos de modelagem falharam em descrever a análise de sensibilidade, calibração e validação. A importância de testar diferentes formas funcionais foi comumente negligenciada e a falta de dados empíricos influenciou a verificação da robustez dos modelos. Por último, nós destacamos a necessidade de desenvolver estudos de modelagem no Hemisfério Sul, incluindo o Brasil, para promover predições que assistam no manejo dos ecossistemas marinhos.

Palavras-chave: modelagem ecológica, plâncton marinho, complexidade de modelos, trofodinâmica.

\section{REFERENCES}

ABER JD. 1997. Why Don't We Believe the Models? Bull Ecol Soc Am 78: 232-233.

ALLEN JI, SIDDORN JR, BLACKFORD JC AND GILBERT FJ. 2004. Turbulence as a control on the microbial loop in a temperate seasonally stratified marine systems model. J Sea Res 52: 1-20.

ANDERSON TR. 2005. Plankton functional type modelling: running before we can walk? J Plankton Res 27: $1073-1081$.

ANDERSON TR, GENTLEMAN WC AND SINHA B. 2010. Influence of grazing formulations on the emergent properties of a complex ecosystem model in a global ocean general circulation model. Prog in Oceanogr 87: 201-213.

ANGELini R, AGOStinho AA AND Gomes LC. 2006. Modelling energy flow in a large Neotropical reservoir: a tool do evaluate fishing and stability. Neotrop Ichthyol 4: 253-260.

ANGELINI R AND PETRERE M. 2000. A model for the plankton system of the Broa reservoir, São Carlos, Brazil. Ecol Modell 126: 131-137.

AraúJo M, Costa M, Aureliano J AND SiLva M. 2008. Mathematical modelling of hydronynamics and water quality in a tropical reservoir, Northeast Brazil. Braz J Aquat Sci Technol 12: 19-30. 
ARHONDITSIS GB AND BRETT MT. 2004. Evaluation of the current state of mechanistic aquatic biogeochemical modelling. Mar Ecol Prog Ser 271: 13-26.

Arhonditsis GB, PApantou D, Zhang W, Perhar G, Massos E AND SHi M. 2008. Bayesian calibration of mechanistic aquatic biogeochemical models and benefits for environmental management. J Mar Syst 73: 8-30.

AYDIN KY, MCFARLANE GA, KING JR, MEGREY BA AND MYERS KW. 2005. Linking oceanic food webs to coastal production and growth rates of Pacific salmon (Oncorhynchus spp.), using models on three scales. Deep-Sea Res 52(Pt II): 757-780.

BAIRD M AND SUTHERS I. 2007. A size-resolved pelagic ecosystem model. Ecol Modell 203: 185-203.

BANAS NS. 2011. Adding complex trophic interactions to a size-spectral plankton model: Emergent diversity patterns and limits on predictability. Ecol Modell 222: 2663-2675.

Banas NS, Lessard EJ, Kudela RM, Maccready P, Peterson TD, Hickeey BM And Frame E. 2009. Planktonic growth and grazing in the Columbia River plume region: A biophysical model study. J Geophys Res 114: COOB06.

BLACKFORD J, ALLEN JI, ANDERSON TR AND ROSE KA. 2010. Challenges for a new generation of marine ecosystem models: Overview of the Advances in Marine Ecosystem Modelling Research (AMEMR) Symposium, 23-26 June 2008, Plymouth UK. J Mar Syst 81: 1-3.

BLACKFORD JC, ALLEN JI AND GILBERT FJ. 2004. Ecosystem dynamics at six contrasting sites: a generic modelling study. J Mar Syst 52: 191-215.

Bonachela JA, RAghiB M AND LeVIN SA. 2011. Dynamic model of flexible phytoplankton nutrient uptake. Proc Natl Acad Sci USA 108: 20633-20638.

BOtSFORD LW, LAWRENCE A, DEVER EP AND LARGIER J. 2003. Wind strength and biological productivity in upwelling systems: an idealized study. Fish Oceanogr 12: 245-259.

BRANDT G AND WIRTZ KW. 2010. Interannual variability of alongshore spring bloom dynamics in a coastal sea caused by the differential influence of hydrodynamics and light climate. Biogeosciences 7: 371-386.

CAPERON J AND MEYER J. 1972. Nitrogen-limited growth of marine phytoplankton. I. Changes in population characteristics with steady-state growth rate. Deep-Sea Res: Oceanogr Abstr 19: 601-618.

CARBONEL CA AND VALENTIN JL. 1999. Numerical modelling of phytoplankton bloom in the upwelling ecosystem of Cabo Frio (Brazil). Ecol Modell 116: 135-148.

CHERIF M AND LOREAU M. 2010. Towards a more biologically realistic use of Droop's equation to model growth under multiple nutrient limitation. Oikos 119: 897-907.

CHU PC, IVANOV LM AND MARGOLINA TM. 2007. On non-linear sensitivity of marine biological models to parameter variations. Ecol Modell 206: 369-382.

CROPP R AND NORBURY J. 2007. Investigations into a plankton population model: Mortality and its importance in climate change scenarios. Ecol Modell 201: 97-117.

DAdOU I, ANDERSEN V, FLIERI GR AND DAVIS C. 1996. Impact of the North Equatorial Current meandering on a pelagic ecosystem: A modelling approach. J Mar Res 54: 311-342.

Deus R, Brito D, KenOv IA, Lima M, Costa V, Medeiros A, NEVEs R And Alves CN. 2013. Three-dimensional model for analysis of spatial and temporal patterns of phytoplankton in Tucuruí reservoir, Pará, Brazil. Ecol Modell 253: 28-43.

DORON M, BRASSEUR P, BRANKART JM, LOSA SN AND MELET A. 2013. Stochastic estimation of biogeochemical parameters from Globcolour ocean colour satellite data in a North Atlantic 3D ocean coupled physical-biogeochemical model. J Mar Syst 117-118: 81-95.

DROOP MR. 1968. Vitamin B12 and marine ecology. IV. The kinetics of uptake, growth, and inhibition in Monochrysis lutheri. J Mar Biol Assoc UK 48: 689-733.

DRUON JN AND LE FÈVRE J. 1999. Sensitivity of a pelagic ecosystem model to variations of process parameters within a realistic range. J Mar Syst 19: 1-26.

DUBE A AND JAYARAMAN G. 2008. Mathematical modelling of the seasonal variability of plankton in a shallow lagoon. Nonlinear Anal Theory, Methods Appl 69: 850-865.

EDWARDS CA, BATCHELDER HP AND POWELL TM. 2000. Modelling microzooplankton and macrozooplankton dynamics within a coastal upwelling system. J Plankton Res 22: 1619-1648.

EVANS GT. 2003. Defining misfit between biogeochemical models and data sets. J Mar Syst 40-41: 49-54.

FASHAM R, DUCKLOW HW AND MCKELVIE SM. 1990. A nitrogen-based model of plankton dynamics in the oceanic mixed layer. J Mar Res 48: 591-639.

FENNEL W. 2010. A nutrient to fish model for the example of the Baltic Sea. J Mar Syst 81: 184-195.

FERNÁNDEZ PB, GÓMEZ AG, ALBA JG, DÍAZ CA AND CORTEZÓN JAR. 2012. A model for describing the eutrophication in a heavily regulated coastal lagoon. Application to the Albufera of Valencia (Spain). J Environ Manage 112: 340-352. 
FLYNN KJ. 2001. A mechanistic model for describing dynamic multi-nutrient, light, temperature interactions in phytoplankton. J Plankton Res 23: 977-997.

FLYNN KJ. 2002. How critical is the critical N:P ratio? J Phycol 38: 961-970.

FLYNN KJ. 2005. Castles built on sand: dysfunctionality in plankton models and the inadequacy of dialogue between biologists and modellers. J Plankton Res 27: 1205-1210.

FlynN KJ, JOHn MST, RAVEn JA, SKIBINSKi DOF, Allen JI, Mitra A AND Hofmann EE. 2015. Acclimation, adaptation, traits and trade-offs in plankton functional type models: reconciling terminology for biology and modelling. J Plankton Res 37: 683-691.

FOLlOWS MJ, DUTKIEWICZ S, GRANT S AND CHISHOLM SW. 2007. Emergent biogeography of microbial communities in a model ocean. Science 315: 1843-1846.

Fragoso CR, MotTa DML, Collischonn W, TuCCI CEM And VAN NeS EH. 2008. Modelling spatial heterogeneity of phytoplankton in Lake Mangueira, a large shallow subtropical lake in South Brazil. Ecol Modell 219: 125-137.

FRANKS PJS. 2002. NPZ models of plankton dynamics: their construction, coupling to physics, and application. J Oceanogr 58: 379-387.

FRANKS PJS. 2009. Planktonic ecosystem models: perplexing parameterizations and a failure to fail. J Plankton Res 31: 12991306.

FREIRE KMF, CHRISTENSEN V AND PAULY D. 2008. Description of the East Brazil Large Marine Ecosystem using a trophic model. Sci Mar 72: 477-491.

FULTON EA. 2010. Approaches to end-to-end ecosystem models. J Mar Syst 81: 171-183.

GARCIA-GORRIZ E, HOEPFFNER N AND OUBERDOUS M. 2003. Assimilation of SeaWiFS data in a coupled physical-biological model of the Adriatic Sea. J Mar Syst 40-41: 233-252.

Gentleman W, Leising A, Frost B, Strom S AND Murray J. 2003. Functional responses for zooplankton feeding on multiple resources: a review of assumptions and biological dynamics. Deep-Sea Res 50(Pt II): 2847-2875.

GENTLEMAN WC AND NEUHEIMER AB. 2008. Functional responses and ecosystem dynamics: how clearance rates explain the influence of satiation, food-limitation and acclimation. J Plankton Res 30: 1215-1231.

GIN KYH, GUO J AND CHEONG H. 1998. A size-based ecosystem model for pelagic waters. Ecol Modell 112: 53-72.

GISMERVIK I AND ANDERSEN T. 1997. Prey switching by Acartia clausi: experimental evidence and implications of intraguild predation assessed by a model. Mar Ecol Prog Ser 157: 247-259.

GREGG WW, GINOUX P, SCHOPF PS AND CASEY NW. 2003. Phytoplankton and iron: validation of a global three-dimensional ocean biogeochemical model. Deep-Sea Res 50(Pt II): 3143-3169.

HANSEN PJ, BJøRSEN PK AND HANSEN BW. 1997. Zooplankton grazing and growth: Scaling within the 2-2,000- $\mu \mathrm{m}$ body size range. Limnol Oceanogr 42: 687-704.

Hernández-CARrasco I, Rossi V, HernándeZ-García E, GARÇON V AND López C. 2014. The reduction of plankton biomass induced by mesoscale stirring: A modelling study in the Benguela upwelling. Deep-Sea Res 83(Pt I): 65-80.

Hinckley S, Coyle KO, Gibson G, Hermann AJ And Dobbins EL. 2009. A biophysical NPZ model with iron for the Gulf of Alaska: Reproducing the differences between an oceanic HNLC ecosystem and a classical northern temperate shelf ecosystem. Deep-Sea Res 56(Pt II): 2520-2536.

HIRST AG, BONNET D AND HARRIS RP. 2007. Seasonal dynamics and mortality rates of Calanus helgolandicus over two years at a station in the English Channel. Mar Ecol Prog Series 340: 189-205.

HOLLING CS. 1959. The components of predation as revealed by a study of small-mammal predation of the European pine sawfly. Can Entomol 91: 293-320.

JACKSON GA. 2001. Effect of coagulation on a model planktonic food web. Deep-Sea Res 48(Pt I): 95-123.

Ji R, CHEN C, Franks PJS, TOWNSEND DW, Durbin EG, BEARDSley RC, LOUGH RG AND Houghton RW. 2006. Spring phytoplankton bloom and associated lower trophic level food web dynamics on Georges Bank: 1-D and 2-D model studies. Deep-Sea Res 53(Pt II): 2656-2683.

JORGENSEN SE. 1994. Fundamentals of ecological modelling. Elsevier Science, Amsterdan, 399 p.

LAI Z, CHEN C, BEARDSLEY RC, ROTHSCHILD B AND TIAN R. 2010. Impact of high-frequency nonlinear internal waves on plankton dynamics in Massachusetts Bay. J Mar Res 68: 259-281.

LE QUÉRÉ C. 2006. Reply to Horizons Article "Plankton functional type modelling: running before we can walk" Anderson (2005): I. Abrupt changes in marine ecosystems? J Plankton Res 28: 871-872.

LE QUÉRÉ C ET AL. 2005. Ecosystem dynamics based on plankton functional types for global ocean biogeochemistry models. Global Change Biol 11: 2016-2040.

LEWIS DM. 2005. A simple model of plankton population dynamics coupled with a LES of the surface mixed layer. J Theor Biol 234: 565-591. 
Macías D, Martin AP, García-Lafuente J, García CM, Yool A, Bruno M, VÁzQuez-Escobar A, IzQuierdo A, SEIN DV AND ECHEVARRÍA F. 2007. Analysis of mixing and biogeochemical effects induced by tides on the AtlanticMediterranean flow in the Strait of Gibraltar through a physical-biological coupled model. Prog Oceanogr 74: $252-272$.

Megrey BA, Rose KA, Ito S, Hay DE, Werner FE, Yamanaka Y And Aita MN. 2007. North Pacific basin-scale differences in lower and higher trophic level marine ecosystem responses to climate impacts using a nutrient-phytoplanktonzooplankton model coupled to a fish bioenergetics model. Ecol Modell 202: 196-210.

MERICO A, BRUGGEMAN J AND WIRTZ K. 2009. A trait-based approach for downscaling complexity in plankton ecosystem models. Ecol Modell 220: 3001-3010.

MiTRA A. 2009. Are closure terms appropriate or necessary descriptors of zooplankton loss in nutrient-phytoplankton-zooplankton type models? Ecol Modell 220: 611-620.

MITRA A ET AL. 2014b. Bridging the gap between marine biogeochemical and fisheries sciences; configuring the zooplankton link. Prog Oceanogr 129: 176-199.

MITRA A AND FLYNN KJ. 2006. Accounting for variation in prey selectivity by zooplankton. Ecol Modell 199: 82-92.

MITRA A ET AL. 2014a. The role of mixotrophic protists in the biological carbon pump. Biogeosciences 11: 995-1005.

MITRA A, FLYNN KJ AND FASHAM MJR. 2007. Accounting for grazing dynamics in nitrogen-phytoplankton-zooplankton models. Limnol Oceanogr 52: 649-661.

MONOD J. 1942. Recherches sur la coissance des cultures bactériennes, $2^{\text {nd }}$ ed., Paris: Hermann, 210 p.

MONTAGNES DJS AND FENTON A. 2012. Prey-abundance affects zooplankton assimilation efficiency and the outcome of biogeochemical models. Ecol Modell 243: 1-7.

MOORE JK, DONEY SC AND LINDSAY K. 2004. Upper ocean ecosystem dynamics and iron cycling in a global three-dimensional model. Global Biogeochem Cy 18: 1-21.

NEWBerger PA, ALlEN JS AND SPITZ YH. 2003. Analysis and comparison of three ecosystem models. J Geophys Res 108: $1-21$.

PAinting S, MOLONEY C AND LUCAS M. 1993. Simulation and field measurements of phytoplankton-bacteria-zooplankton interactions in the southern Benguela upwelling region. Mar Ecol Prog Ser 100: 55-69.

PERHAR G, ARHONDITSIS GB AND BRETT MT. 2013. Modeling zooplankton growth in Lake Washington: A mechanistic approach to physiology in a eutrophication model. Ecol Modell 258: 101-121.

PIERCE DW. 2004. Future changes in biological activity in the North Pacific due to anthropogenic forcing of the physical environment. Clim Change 62: 389-418.

POLOVINA JJ. 1984. Model of a coral reef ecosystem I: the Ecopath model and its application to French Frigate Shoals. Coral Reefs 3: 1-11.

PTACNIK R, SOMMER U, HANSEN T AND MARTENS V. 2004. Effects of microzooplankton and mixotrophy in an experimental planktonic food web. Limnol Oceanogr 49: 1435-1445.

R CORE TEAM. 2016. R: A language and environment for statistical computing. R Foundation for Statistical Computing, Vienna, Austria. URL https://www.R-project.org/.

RICHARDSON A. 2008. In hot water: zooplankton and climate change. ICES J Mar Sci 65: 279-295.

RILEY GA. 1946. Factors controlling phytoplankton populations on Georges Bank. J Mar Res 38: 89-114.

Rocha GRA, Rossi-Wongtschowski C, PIRES-VAnIN AM AND SOARES LSH. 2007. Trophic models of São Sebastião Channel and continental shelf systems, SE Brazil. Panam J Aquat Sci 2: 149-162.

Roy S, Broomhead DS, Platt T, SATHYEndRANATH S AND CiaVATTA S. 2012. Sequential variations of phytoplankton growth and mortality in an NPZ model: A remote-sensing-based assessment. J Mar Syst 92: 16-29.

SAITO H AND KIØRBOE T. 2001. Feeding rates in the chaetognath Sagitta elegans: effects of prey size, prey swimming behaviour and small-scale turbulence. J Plankton Res 23: 1385-1398.

SAIZ E. 1994. Observations of the free-swimming behavior of Acartia tonsa: Effects of food concentration and turbulent water motion. Limnol Oceanogr 39: 1566-1578.

SEEL A, KEUREN VD AND MADIN L. 2001. Predation by omnivorous copepods on early developmental stages of Calanus finmarchicus and Pseudocalanus spp. Limnol Oceanogr 46: 953-959.

STEELE JH. 1958. The quantitative ecology of marine phytoplankton. Biol Rev 34: 129-158.

STEELE JH AND GIFFORD DJ. 2010. Reconciling end-to-end and population concepts for marine ecosystems. J Mar Syst 83: 99103.

STEELE JH AND HENDERSON EW. 1992. The role of predation in plankton models. J Plankton Res 14: 157-172.

STICKNEY HL, HOOD RR AND STOECKER DK. 2000. The impact of mixotrophy on planktonic marine ecosystems. Ecol Modell 125: $203-230$ 
Stow CA, Jolliff J, MCGillicuddy DJ, Doney SC, Allen Ji, Friedrichs MAM, Rose KA AND WALLhEAD P. 2009. Skill assessment for coupled biological/physical models of marine systems. J Mar Syst 76: 4-15.

STUART V AND VERHEYE HM. 1991. Diel migration and feeding patterns of the chaetognath, Sagitta friderici, off the west coast of South Africa. J Mar Syst 49: 493-515.

THINGSTAD FT, STRAND E AND LARSEN A. 2010. Stepwise building of plankton functional type (PFT) models: A feasible route to complex models? Prog Oceanogr 84: 6-15.

VALENTIN JL AND COUTINHO R. 1990. Modelling maximum chlorophyll in the Cabo Frio (Brazil) upwelling: a preliminary approach. Ecol Modell 52: 103-113.

VIHERLUOTO M AND ViITASALO M. 2001. Temporal variability in functional responses and prey selectivity of the pelagic mysid, Mysis mixta, in natural prey assemblages. Mar Biol 138: 575-583.

Vogt M, VAllina SM, Buitenhuis ET, BopP L AND LE QUÉRÉ C. 2010. Simulating dimethylsulphide seasonality with the Dynamic Green Ocean Model PlankTOM5. J Geophys Res 115: C06021.

WARD BA, DUTKIEWICZ S, JAHN O AND FOLLOWS MJ. 2012. A size-structured food-web model for the global ocean. Limnol Oceanogr 57: 1877-1891.

WARD BA, FRIEDRICHS MAM, ANDERSON TR AND OSCHLIES A. 2010. Parameter optimisation techniques and the problem of underdetermination in marine biogeochemical models. J Mar Syst 81: 34-43.

WOLFF M, KOCH V AND ISAAC V. 2000. A trophic flow model of the Caeté Mangrove Estuary (North Brazil) with considerations for the sustainable use of its resources. Estuarine, Coastal Shelf Sci 50: 789-803.

XU J AND HoOD RR. 2006. Modelling biogeochemical cycles in Chesapeake Bay with a coupled physical-biological model. Estuarine, Coastal Shelf Sci 69: 19-46.

Yool A, Popova EE, COWARD AC, BERNIE D AND ANDERSON TR. 2013. Climate change and ocean acidification impacts on lower trophic levels and the export of organic carbon to the deep ocean. Biogeosciences 10: 5831-5854.

ZHAO Q AND LU X. 2008. Parameter estimation in a three-dimensional marine ecosystem model using the adjoint technique. J Mar Syst 74: 443-452.

\section{SUPPLEMENTARY MATERIAL}

TABLE SI - Summary of the models used in this study showing publication year, model type (NPZ, NPZD, SS, and/or PFT), application ( $\mathrm{T}=$ theoretical; $\mathrm{H}=$ heuristic; $\mathrm{P}=$ predictive $)$, approach $(\mathrm{B}=$ biological; $\mathrm{PB}=$ physical-biological; $\mathrm{BQ}=$ biogeochemical), and the performance or not of conventional modeling procedures, i.e. sensitivity analysis, calibration, and validation $($ par $=$ partial and tot $=$ total $)$. 